\title{
In A Bind With Your Significant Other? Here Is How to Remedy Your Mood in Time for the Holidays
}

\author{
*Sandra Fragomeni \\ Northcentral University, USA \\ Submission: December 23, 2016; Published: January 03, 2017 \\ *Corresponding author: Sandra Fragomeni, North central University, USA, Tel: 516-437-4892; Email: sandyf8415@gmail.com
}

\section{Short Communication}

Are you unhappy with your significant other at the moment? Above all, your romantic partner? Experiencing feelings of frustration, anger, or resentment from time to time when you feel unheard? Gottman (1999) maintains that it is normal as long as you don't hold on to it or feel superior to your partner in any way. Holding on to anger is unhealthy. Forgive and move on. After all, we all have things we can improve on. Communicate with your partner about what is bothering you and why. Work together as a team to find solutions that work. Reach an understanding. It might help to try to remember your Love Map; that is, how you met and fell in love. Understanding who your partner is and what makes him/her happy is beneficial. Who knows, you may discover something about your partner others are not aware of. This may strengthen your bond together. Be willing to express admiration and respect.

The Sound Relationship House (SRH) created by Gottman (1999), lists the following, in addition to the love map and admiration system, as positive things you can do for your partner. They are; be open with one another, share stories and schedule time when you can be together, give him/her the "benefit of the doubt" where it is due, solve problems by acknowledging your personality differences, work together to make each other's dreams come true, and create shared meaning in creating goals or rituals you can both share. Doing so will change your thoughts towards your partner. You will notice a change in his/her behavior as well as your own as you gain an understanding of one another. Your mood will shift from one of anger to happiness. As the holidays are approaching, take the time to get to know his/her friends and family members.
What are they like? What are the important events coming up in your partner's life? The SRH suggests that you convey to one another the behavioral changes you wish to see in your partner. This does not mean that you can change them or their personality. If your aim is to change them, then that is not love. Share with them the behaviors that bother you and strive to work around them. For instance; if he/she is not a good cook but you are, perhaps you may take over that role, if you are poor at organizing or cleaning up, he/she can retain this role, etc.

Dr. Gottman's research on maintaining healthy relationships demonstrates that:

1. Instead of criticizing, complain without blaming, using "I" rather than "you" statements.

2. Instead of frequently defending yourself, take responsibility for your actions.

3. Rather than using contempt (disrespect), build a culture of appreciation.

4. Instead of stonewalling, use gentle and calming techniques with your partner rather than walking away from the conversation. Moving away from the conversation accomplishes nothing.

Uncover the behaviors and rituals that work for you. Friendship, admiration, communication, compromise, and respect are key remedies to a happy and successful relationship. 
Your next submission with JuniperPublishers will reach you the below assets

- Quality Editorial service

- Swift Peer Review

- Reprints availability

- E-prints Service

- Manuscript Podcast for convenient understanding

- Global attainment for your research

- Manuscript accessibility in different formats

( Pdf, E-pub, Full Text, Audio)

- Unceasing customer service

Track the below URL for one-step submission https://juniperpublishers.com/online-submission.php 